\title{
Thermographic variation of the udder of dairy ewes in early lactation and following an Escherichia coli endotoxin intramammary challenge in late lactation
}

\author{
A. Castro-Costa, ${ }^{*}$ G. Caja, ${ }^{* 1}$ A. A. K. Salama, ${ }^{\star} \dagger$ M. Rovai, ${ }^{\star}$ C. Flores, ${ }^{*}$ and J. Aguilół \\ *Grup de Recerca en Remugants (G2R), Departament de Ciència Animal i dels Aliments, Universitat Autònoma de Barcelona, 08193 Bellaterra, \\ Spain \\ †Sheep and Goat Research Department, Animal Production Research Institute, 12311 Dokki, Giza, Egypt \\ †Departament de Microelectrònica i Sistemes Electrònics, Universitat Autònoma de Barcelona, 08193 Bellaterra, Spain
}

\begin{abstract}
A total of 83 lactating dairy ewes (Manchega, $n$ $=48$; Lacaune, $\mathrm{n}=35$ ) were used in 2 consecutive experiments for assessing the ability of infrared thermography (IRT) to detect intramammary infections (IMI) by measuring udder skin temperatures (UST). In experiment 1 , ewes were milked twice daily and IRT pictures of the udder were taken before and after milking at 46 and $56 \mathrm{~d}$ in milk (DIM). Milk yield was 1.46 $\pm 0.04 \mathrm{~L} / \mathrm{d}$, on average. Detection of IMI was done using standard bacterial culture by udder half at 15 , 34, and 64 DIM. Twenty-two ewes were classified as having IMI in at least one udder half, the others being healthy (142 healthy and 24 IMI halves, respectively). Four IMI halves had clinical mastitis. No UST differences were detected by IMI and udder side, being 32.94 $\pm 0.04^{\circ} \mathrm{C}$ on average. Nevertheless, differences in UST were detected for breed (Lacaune - Manchega $=0.35$ $\pm 0.08^{\circ} \mathrm{C}$ ), milking process moment (after - before $=0.13 \pm 0.11^{\circ} \mathrm{C}$ ), and milking schedule (p.m. - a.m. $\left.=0.79 \pm 0.07^{\circ} \mathrm{C}\right)$. The UST increased linearly with ambient temperature $(\mathrm{r}=0.88)$. In experiment 2 , the UST response to an Escherichia coli O55:B5 endotoxin challenge $(5 \mu \mathrm{g} / \mathrm{udder}$ half) was studied in 9 healthy Lacaune ewes milked once daily in late lactation $(0.58$ $\pm 0.03 \mathrm{~L} / \mathrm{d} ; 155 \pm 26 \mathrm{DIM})$. Ewes were allocated into 3 balanced groups of 3 ewes to which treatments were applied by udder half after milking. Treatments were (1) control (C00, both udder halves untreated), (2) half udder treated (T10 and C01, one udder half infused with endotoxin and the other untreated, respectively), and (3) treated udder halves (T11, both udder halves infused with endotoxin). Body (vaginal) temperature and UST, milk yield, and milk composition changes were monitored by udder half at different time intervals
\end{abstract}

Received April 30, 2013.

Accepted November 18, 2013.

${ }^{1}$ Corresponding author: gerardo.caja@uab.es
(2 to $72 \mathrm{~h}$ ). First local and systemic signs of IMI were observed at 4 and $6 \mathrm{~h}$ postchallenge, respectively. For all treatments, UST increased after the challenge, peaking at $6 \mathrm{~h}$ in $\mathrm{T} 11$ (which differed from that in $\mathrm{C} 00, \mathrm{C} 01$, and T10), and decreased thereafter without differences by treatment. Vaginal temperature and milk somatic cell count increased by $6 \mathrm{~h}$ postchallenge, whereas lactose content decreased, in the endotoxin-infused udder halves. Effects of endotoxin on lactose and somatic cell count values were detectable in the infused udder halves until $72 \mathrm{~h}$. In conclusion, despite the accuracy of the camera $\left( \pm 0.15^{\circ} \mathrm{C}\right)$ and the moderate standard errors of the mean obtained for UST measures $( \pm 0.05$ to $0.24^{\circ} \mathrm{C}$ ), we were unable to discriminate between healthy and infected (subclinically or clinically) udder halves in dairy ewes.

Key words: dairy sheep, infrared thermography, mastitis detection, udder temperature

\section{INTRODUCTION}

Early diagnosis of IMI is a relevant topic in the dairy industry because of the effects of IMI on milk production and treatment-related costs. Animals respond to IMI locally (i.e., pain, heat, hardness, swelling) and systemically (i.e., antibody production, body temperature), but the response may vary according to the infectious agent (Rebhun, 1995; McGavin and Zachary, 2007). Thermal response to infection (fever) is a useful diagnostic indicator that can be observed locally in most IMI cases (Rebhun, 1995).

Infrared thermography (IRT) is a noninvasive technique that allows the temperature of a surface to be measured without contact. Infrared thermography can generate images of the amount of heat emitted by an object, which has been used to study the changes in udder surface temperature (UST) caused by IMI in dairy cows (Barth, 2000; Scott et al., 2000; Hovinen, 2009). Moreover, IRT is able to show changes in teat temperature according to milking parameters in dairy 
cows (Kunc et al., 2007; Vegricht et al., 2007) and dairy ewes (Murgia et al., 2008). Barth (2000) concluded that IRT showed promise for detecting clinical mastitis, although it was unlikely to be useful for detection of subclinical mastitis.

Berry et al. (2003) reported daily variations in UST of dairy cows measured by IRT as a consequence of exercise, ambient temperature, and circadian rhythm, concluding that UST can be predicted accurately and that the difference between actual and predicted temperature was useful for detecting mastitis. In this sense, Colak et al. (2008) and Polat et al. (2010) indicated that IRT had a predictive diagnostic ability similar to that of the California mastitis test (CMT) in dairy cows. Reported UST changes as a result of the IMI-like process induced by infusing Escherichia coli bacteria or the endotoxin LPS in dairy cows varied between 1.0 and $3.0^{\circ} \mathrm{C}$ (Hovinen et al., 2008; Pezeshki et al., 2011), similar to the range of accuracy of most IRT cameras. Nevertheless, Hovinen et al. (2008) stressed that UST changes may be affected by the vasoconstriction of the peripheral blood vessels observed during many IMI episodes.

The aim of this study was to evaluate the use of IRT to measure UST changes produced by dairy sheep breed and machine milking and to assess the use of IRT for detecting naturally occurring IMI and IMI induced by $E$. coli endotoxin infusion in early and late lactation, respectively.

\section{MATERIALS AND METHODS}

The treatment procedures and animal care conditions were reviewed and approved by the Ethical Committee on Animal and Human Experimentation of the Universitat Autònoma de Barcelona (reference CEEAH 2011/1056).

\section{Experiment 1}

Animal and Management Conditions. A total of 83 lactating dairy ewes (Manchega, $\mathrm{n}=48$; Lacaune, $\mathrm{n}=35$ ) from the Experimental Farm of the "Servei de Granges i Camps Experimentals" (SGCE) of the UAB (Bellaterra, Barcelona, Spain) were used after parturition. Ewes were kept in a semi-confinement system, allowed to graze for $6 \mathrm{~h}$ daily on an annual Italian ryegrass prairie, and supplemented indoors with alfalfa hay ad libitum (1.27 Mcal of $\mathrm{NE}_{\mathrm{L}} / \mathrm{kg}$ and $20.1 \%$ CP; DM basis) and concentrate pellets at a flat rate of $0.8 \mathrm{~kg} / \mathrm{d}\left(1.75 \mathrm{Mcal}\right.$ of $\mathrm{NE}_{\mathrm{L}} / \mathrm{kg}$ and $16.5 \% \mathrm{CP}$; DM basis) distributed in 2 portions at milking time. After the weaning of the lambs (d 35), the ewes were milked by machine twice daily (0800 and $1700 \mathrm{~h}$ ) in a double-12 stall parallel milking parlor (Amarre Azul I, DeLaval Equipos, Alcobendas, Madrid, Spain) with a central high milk pipeline, 12 DeLaval SG-TF100 milking clusters, and 12 MM25SG milk flow and recording units (both from DeLaval, Tumba, Sweden). Milking was performed at a vacuum of $40 \mathrm{kPa}, 120$ pulses/min, and $50 \%$ pulsation ratio. The milking routine included cluster attachment (without udder preparation), machine milking, and automatic cluster detachment (milk flow rate $<0.1 \mathrm{~L} / \mathrm{min}$ or milking time $>3 \mathrm{~min}$ ). Teat dipping with an iodine solution (P3-ioshield, Ecolab Hispano-Portuguesa, Barcelona, Spain) was done at the end of milking. On experimental days, teat dipping was done after taking the IRT pictures.

Milk Recording and Sampling. Milk yield of individual ewes was recorded at 60 DIM. Udders and milk were clinically examined for clinical signs of IMI (e.g., hypersensitivity, hardness, abnormal texture, swelling, and hyperthermia) and for physical milk changes (i.e., milk clots and color and consistency changes) according to NMC (1999). Detection of IMI by bacterial culture of foremilk samples were performed by udder half at 15 , 34 , and 64 DIM.

Milk samples were taken aseptically from each mammary gland before milking. Teats were dipped in an iodine solution (P3-ioshield), dried with disposable paper towels, and dipped in ethanol $70 \%$ before sampling. The initial milk squirts were discarded and approximately $5 \mathrm{~mL}$ was collected in sterile tubes with plastic caps, preserved under refrigeration $\left(4^{\circ} \mathrm{C}\right)$, and processed on the same day. Milk samples were cultured using conventional methods, and $0.01 \mathrm{~mL}$ was streaked onto blood agar plates (Agar Sangre 90 mm, Lab. Conda, Torrejón de Ardoz, Madrid, Spain) and plates incubated at $37^{\circ} \mathrm{C}$. Plates were examined for bacterial growth after 18, 24, and $48 \mathrm{~h}$.

UST. The UST was measured using a handheld portable infrared imaging camera (IRI 4010, Irisys, Northampton, UK). The camera operated within the 8 to $14 \mu \mathrm{m}$ spectral band and $\pm 0.15^{\circ} \mathrm{C}$ thermal resolution (accuracy). Before each measurement, the camera was adjusted for the ambient temperature conditions of each scanning $\left(9\right.$ to $26^{\circ} \mathrm{C}$ ) to compensate the reflected temperature. The emissivity value was set to 0.98 according to the Irisys camera user's manual, which is the value commonly used for measuring the skin temperature in humans and in dairy cow udders (Hovinen et al., 2008).

The IRT pictures of each udder were taken immediately before and after milking at 46 and 56 DIM. Ewes were restrained in a standing position using the head locker of the milking parlor, and udder pictures were taken from a caudal view, placing the camera on a tripod at a distance of $0.5 \mathrm{~m}$. Udders were free of debris or 

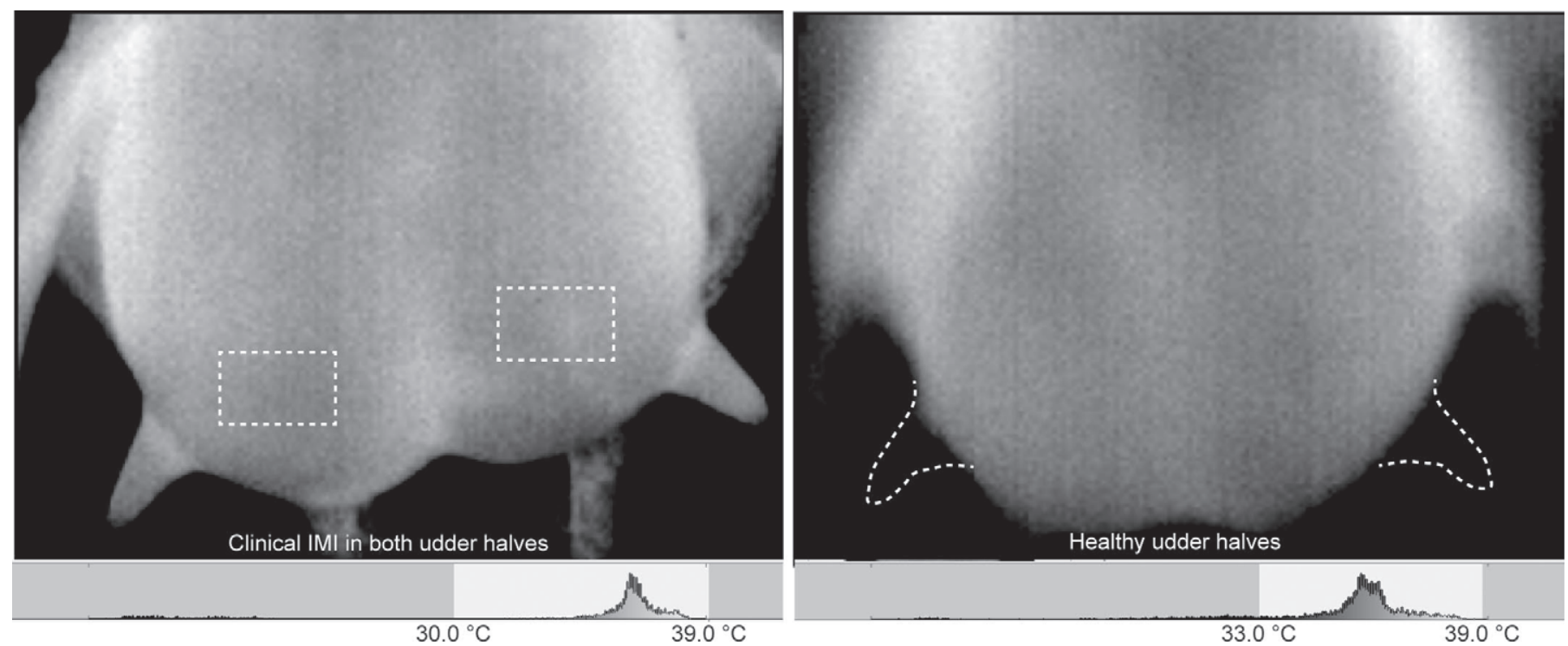

Figure 1. Infrared thermographic images of clinically intramammary infected udder halves (left) and healthy udder halves (right) of dairy ewes in the milking parlor (indoor ambient temperature ranging between 14.1 and $15.9^{\circ} \mathrm{C}$ ). Thermal histogram of the full image is shown under each image and udder skin temperature extreme values are indicated. Dotted rectangles on each udder half are the selected frame of $55 \times 40$ pixels in which the skin temperature was measured.

fecal materials. Infrared images were downloaded and the UST points analyzed with appropriate computer software (Irisys 4000 Series Imager v.1.0.0.17). Representative UST values of each udder half were obtained from the full udder IRT images $(640 \times 480$ pixels $)$ by selecting a rectangle of $55 \times 40$ pixels in the center of the cisternal part of each udder half (Figure 1). Special care was taken to avoid the influence of heat from the groin, leg, and median suspensory ligament, as they showed higher temperatures than the rest of the udder. Mean UST for each udder half was obtained using a $4 \times$ zoom by averaging the temperatures recorded in the center of each side of the selected rectangle.

Skin thickness of the udder was measured after the p.m. milking in duplicate in a random sample of 10 ewes of each breed with healthy udders. With this aim, the width of a fold of udder skin in 2 positions at the middle line of the udder perineal region (escutcheon) was measured at the end of the experiment and approximately $4 \mathrm{~h}$ after milking using a stainless steel electronic digital caliper (Yicheng, Beijing, China).

\section{Experiment 2}

Animal and Management Conditions. Nine healthy primiparous Lacaune dairy ewes $(60.2 \pm 0.8$ $\mathrm{kg}$ of BW) at the end of lactation (155 \pm 26 DIM and $0.58 \pm 0.03 \mathrm{~L} / \mathrm{d}$ ) from the Experimental Farm of SGCE were used. Ewes were maintained indoors in straw-bedded pens $\left(1 \mathrm{~m}^{2} /\right.$ ewe $)$ and fed a mix of alfalfa and tall fescue hays (2:1) ad libitum and the same concentrate mixture $(0.6 \mathrm{~kg} / \mathrm{d}$, as fed $)$ used in experiment 1 . Oncedaily milking was conducted $(0800 \mathrm{~h})$ in a 12-stall milking parlor (Westfalia-Surge Ibérica, Granollers, Spain) equipped with recording jars $(2 \mathrm{~L} \pm 5 \%)$ and a low milk pipeline. Milking was performed at a vacuum of $42 \mathrm{kPa}$, 120 pulses/min, and a $50 \%$ pulsation ratio. The milking routine included cluster attachment, machine milking, machine stripping before cluster removal, and teat dipping in a iodine solution (P3-ioshield).

No signs of IMI were detected in any udder half by either clinical examination or CMT (Insvet, Esplus, Huesca, Spain) of foremilk before the experiment. Absence of IMI was also confirmed by bacterial culture as done in experiment 1.

Ewes were assigned to 3 balanced groups of 3 ewes to which the experimental treatments were randomly applied.

Endotoxin Challenge. Treatments consisted of intramammary challenges of Escherichia coli serotype O55:B5 LPS (Sigma-Aldrich, St Louis, MO) to induce an intramammary response similar to a mastitis-like process, and were as follows: (1) control (C00, both udder halves untreated; $\mathrm{n}=3$ ewes), (2) half udder treated (T10 and C01, one udder half was LPS infused and the other half was untreated, respectively; $\mathrm{n}=3$ ewes), and (3) both udder halves treated (T11, both udder halves were LPS infused; $\mathrm{n}=3$ ewes).

A solution of $5 \mu \mathrm{g} / \mathrm{mL}$ of $E$. coli O55:B5 LPS in physiological saline $(0.9 \% \mathrm{NaCl}$; B Braun, Barcelona, 
Spain) was aseptically prepared and preserved in 1-mL sterilized vials under refrigeration $\left(4^{\circ} \mathrm{C}\right)$. The LPS challenge consisted of infusing $1 \mathrm{~mL}$ of LPS solution (5 $\mu \mathrm{g} / \mathrm{udder}$ half) through the teat canal of the T10 (half udder) and T11 (both udder halves) ewe udders by using individual aseptic plastic cannulas (model J-2, Jorgensen Laboratories, Loveland, CO) cut to a length of $18 \mathrm{~mm}$ and with an outside diameter of $2.5 \mathrm{~mm}$ at approximately $30 \mathrm{~min}$ after the morning milking.

Clinical Observations and Milk Sampling. The experimental period lasted for $3 \mathrm{~d}$, in which the clinical and productive stages of the udder halves were monitored after the challenge. Systemic (body temperature and udder appearance) and local (redness, hardness and UST) signs of reaction to the LPS challenge were monitored at $1 \mathrm{~h}$, every $2 \mathrm{~h}$ from 2 to $12 \mathrm{~h}$, every $12 \mathrm{~h}$ from 12 to $72 \mathrm{~h}$, and additionally at 25, 28, 32, 49, and $73 \mathrm{~h}$ postchallenge.

Body temperature (systemic sign of reaction) was measured vaginally at the above indicated times using a clinical thermometer (Mini color, ICO Technology, Barcelona, Spain; range: 32.0 to $43.9^{\circ} \mathrm{C}$; accuracy: $\pm 0.1^{\circ} \mathrm{C}$ ). Udders and milk were also subjected to physical examination for IMI according to experiment 1 procedures.

Milk yield was recorded and milk samples collected (for CMT, milk composition, and SCC) by udder half during the preexperimental week and at each milking throughout the experiment (d 1 to 3 ). Additional milk samples were collected manually at $6,24,48$, and $72 \mathrm{~h}$ postchallenge. For milk composition and SCC analyses, samples of approximately $50 \mathrm{~mL}$ were preserved with antimicrobial tablets (Bronopol, Broad Spectrum Micro-tabs II, D\&F Control Systems Inc., San Ramon, CA) and kept at $4^{\circ} \mathrm{C}$ until processing. Both milk composition and SCC were determined in the interprofessional dairy laboratory of Catalonia (Allic, Cabrils, Barcelona, Spain), using an automatic somatic cell counter (Fossomatic 500, Foss-Electric, Hillerød, Denmark) previously calibrated for ewe milk.

$\boldsymbol{U S T}$. The UST was measured using the procedure described in experiment 1 , taking 17 IRT images from each ewe's udder immediately before and at different times after the challenge (same times as for body temperatures). Images were obtained from the untouched udders, before udder examination and milk sampling, to avoid stress-induced hyperthermia (Bouwknecht et al., 2007).

\section{Statistical Analyses}

Data of both experiments were analyzed using the PROC MIXED (version 9.1; SAS Institute Inc., Cary, $\mathrm{NC}$ ) and variation factors compared by classes. The mixed model used for experiment 1 data contained the fixed effects of udder health (healthy and IMI), breed (Manchega and Lacaune), milking moment (before and after), and milking schedule (a.m. and p.m.), and the random effects of ewe (1 to 83) and error.

The model used in experiment 2 contained the fixed effects of treatment (C00, T11, C01, and T10), time postchallenge ( 0 to $73 \mathrm{~h}$ ), and the random effects of ewe (1 to 9) and error. Performance data before the LPS challenge were used as a covariate to correct for individual initial differences, and results were presented as least squares means. Differences between least squares means were determined with the PDIFF option of SAS. Logarithmic transformations $\left(\log _{10}\right)$ of SCC values were used in the statistical analysis. Pearson correlations were used to determine the relationship between the studied variables. Significance was declared as $P<$ 0.05 , unless otherwise indicated, and tendencies were discussed at $P<0.10$.

\section{RESULTS AND DISCUSSION}

\section{Experiment 1}

Milk Yield. Experimental ewes yielded $1.46 \pm 0.04$ $\mathrm{L} / \mathrm{d}$, on average, at $60 \mathrm{DIM}$. When classified according to bacterial culture, subclinical IMI ewes yielded $12 \%$ less milk than healthy ewes, although the difference was not significant $(1.37 \pm 0.08$ vs. $1.49 \pm 0.06 \mathrm{~L} / \mathrm{d}$; $P=0.21)$. A lower milk yield was expected in the IMI ewes according to different studies (Viguier et al., 2009; Pezeshki et al., 2011), although the difference from the healthy ewes may have been smaller because of the low incidence of udder halves having subclinical mastitis (12.1\%) and the compensatory milk yield of the contralateral udder half (Leitner et al., 2004).

Subclinical Mastitis. From the 166 udder halves studied, 20 (12.0\%) were classified as IMI by bacterial culture in at least 2 of the 3 tests at 15,34, and 64 DIM. The subclinical IMI ewes did not present signs of mastitis and their milk was apparently normal but showed high SCC $\left(>300 \times 10^{3}\right.$ cells $/ \mathrm{mL}$, according to McDougall et al., 2001). Reported values of the incidence of subclinical mastitis are markedly greater in dairy cows than in ewes (Lam et al., 2013; 22 to $23 \%$ ).

No differences in UST values were detected between healthy and subclinical IMI udders of the same ewes throughout the experiment, but the IMI udders tended to show slightly lower mean UST values than the healthy udders (33.13 vs. $33.61^{\circ} \mathrm{C}$, respectively; $\mathrm{SEM}= \pm 0.28$; $P=0.10)$. These results are in contrast to those of Martins et al. (2013), who reported greater UST values in subclinical mastitis than in healthy udders of Santa Inês ewes (37.46 vs. $37.05^{\circ} \mathrm{C}$, respectively), although the 
Table 1. Effect of the experimental variation factors on the udder skin temperatures $\left(\mathrm{UST},{ }^{\circ} \mathrm{C}\right.$ ) of dairy ewes

\begin{tabular}{lcccc}
\hline Factor $^{1}$ & Class 1 & Class 2 & SEM & Effect $(P=)$ \\
\hline Breed & 32.88 & 33.23 & 0.11 & 0.003 \\
Milking schedule & 32.66 & 33.45 & 0.06 & 0.001 \\
Milking moment & 32.99 & 33.12 & 0.05 & 0.01 \\
Side of the udder & 33.05 & 33.06 & 0.11 & 0.88 \\
Health status of udder & 33.11 & 33.00 & 0.16 & 0.48 \\
\hline
\end{tabular}

${ }^{1}$ Factor classes: breed (class 1, Manchega; class 2, Lacaune), milking schedule (class 1, a.m.; class 2, p.m.), milking moment (class 1, before; class 2, after), side of the udder (class 1, left; class 2, right) and health status of udder (class 1, healthy; class 2, subclinical IMI).

number of ewes (healthy, 16; subclinical mastitis, 8), size of the udder (meat sheep), and the cleaning process (using warm water) may have conditioned the results. Moreover, no differences were reported by Martins et al. (2013) for total udder mean temperatures (36.30 vs. $36.06^{\circ} \mathrm{C}$, respectively).

Clinical Mastitis. A total of 4 udder halves (from 3 ewes, 3.6\%) showed clinical mastitis and required antibiotic treatment. These IMI udders showed local and systemic mastitis clinical signs (severe swelling, tissue hardness, and redness) and marked changes in milk appearance (flakes, watery, and abnormal texture). Prevalence of clinical mastitis is generally $\leq 5 \%$ in dairy sheep (Berger et al., 2004), in agreement with our data. The incidence of clinical mastitis is markedly greater in dairy cows compared with dairy sheep, ranging between 28 and $33.5 \%$ quarter cases as reported in Canada (Olde Riekerink et al., 2008) and the Netherlands (Lam et al., 2013).

Mean UST values for clinical IMI varied greatly and, on average, were slightly higher than for the healthy udder halves, although they did not differ significantly (33.51 vs. $33.47^{\circ} \mathrm{C}$, respectively; $\mathrm{SEM}= \pm 1.13 ; P=$ 0.97). Infrared thermography images of the only ewe presenting clinical IMI in both udder halves compared with a fully healthy udder are shown in Figure 1 (hightemperature pixels are shown by lighter gray color). Martins et al. (2013) reported lower UST values but no differences between clinical mastitis and healthy udders ( 36.67 vs. $37.05^{\circ} \mathrm{C} ; \mathrm{n}=13$ ); the lower UST values were thought to be a response to the decreased blood flow that occurred due to mammary gland loss of function. Moreover, Hovinen et al. (2008) indicated that UST changes may be affected by the vasoconstriction of the peripheral blood vessels observed during IMI episodes, producing a decrease in skin temperature.

Udder Temperature Variation Factors. Table 1 summarizes the effects of the main factors considered in the study to explain the variation of UST values in the experimental ewes. Overall mean UST $\left(32.94 \pm 0.04^{\circ} \mathrm{C}\right)$ was lower than the average body temperature reported for sheep (38.0 to $39.5^{\circ} \mathrm{C}$; Adams and McKinley, 2009) and was affected by most of the studied factors (i.e., breed, milking schedule, and milking moment; $P<$ 0.05 to 0.001$)$. Values of UST were lower in Manchega compared with Lacaune ewes $(P<0.01$; Table 1$)$, which agrees with the lower milk yield observed for the healthy ewes in our study (1.25 vs. $1.72 \mathrm{~L} / \mathrm{d} ; \mathrm{SEM}= \pm$ $0.97 ; P<0.001)$. No previous data on the relationship of milk yield and UST has been reported. Moreover, no differences in udder skin fold thickness were detected between Manchega and Lacaune ewes (15.82 \pm 0.13 vs. $15.79 \pm 0.07 \mathrm{~mm}$, respectively; $P=0.90)$, but we noted that Manchega ewes more frequently had hair on their udders than Lacaune. According to Mitchell (2013), presence of hair may have decreased the UST values and contributed to the breed differences reported here.

The UST values before milking were lower at the morning milking than at the afternoon milking $(P<$ 0.001 ; Table 1 ), which may be related to the circadian rhythm of body temperatures and exercise and feeding behavior (Berry et al., 2003; Piccione and Caola, 2003; D'Alterio et al., 2011). Moreover, UST correlated with ambient temperature $(\mathrm{y}=0.37 \mathrm{x}+28.4 ; \mathrm{r}=0.88 ; P<$ $0.001)$. Indoor ambient temperature was $12.18 \pm 0.74^{\circ} \mathrm{C}$ on average, ranging between 9.1 and $16.6^{\circ} \mathrm{C}$ during the experiment. Loughmiller et al. (2001) also reported a correlation $(\mathrm{r}=0.98)$ between ambient temperature $(10$ to $32^{\circ} \mathrm{C}$ ) and body surface temperature measured by IRT in pigs; each $1^{\circ} \mathrm{C}$ increment in ambient temperature caused an increase of $0.40^{\circ} \mathrm{C}$ in the body surface temperature of pigs.

Additionally, UST values increased by effect of milking $(P<0.05$; Table 1$)$, which agreed with the conclusions of Kunc et al. (2007) and was attributed to the hyperemia caused by udder manipulation. Figure 2 shows the IRT images of the udder of the same ewe before and after milking. Nevertheless, Murgia et al. (2008) in sheep and Aljumaah et al. (2012) in camels reported a decrease in the temperature of the teats and the udder, measured by IRT, as a consequence of machine milking. Differences in the UST response to machine milking may also be due to the operating vacuum and milk yield (Kunc et al., 2007). Vegricht et al. (2007) reported smaller increments in UST in dairy cows with lower milking vacuums. 


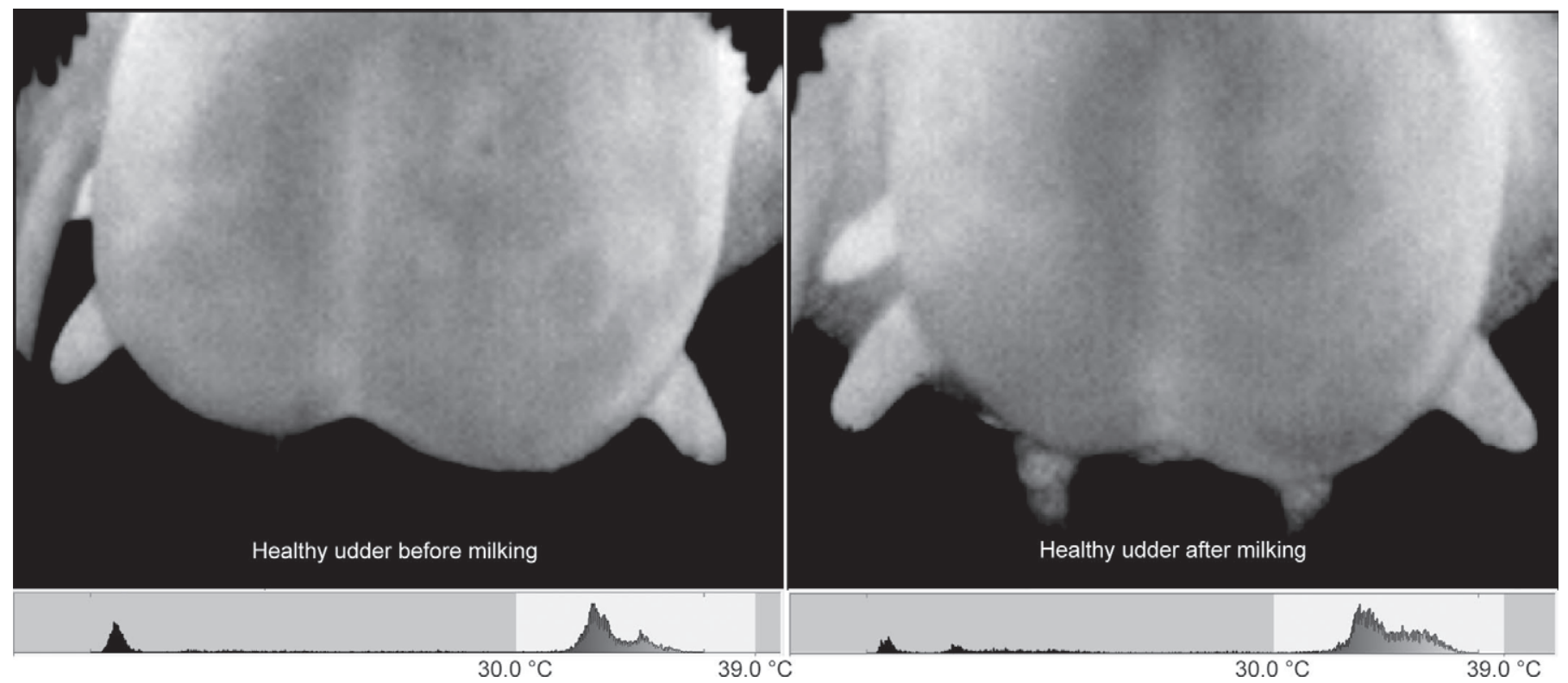

Figure 2. Infrared thermographic images of healthy udders of dairy ewes before (left) and after (right) milking in the milking parlor (indoor ambient temperature ranging between 14.3 and $16.0^{\circ} \mathrm{C}$ ). Thermal histogram is shown under each image and udder skin temperature extreme values are indicated. Note the presence of a supernumerary teat in the left udder half.

No effects were detected in our ewes with respect to udder side or udder health status $(P>0.05$; Table 1$)$, allowing us to use pooled data and agreeing with the IMI data discussed above.

\section{Experiment 2}

Clinical Signs and Body Temperature. Local and systemic signs of IMI in the T10 and T11 mammary glands were clearly observed after LPS infusion, despite the low dose used per udder half $(0.083 \mu \mathrm{g} /$ $\mathrm{kg}$ of BW). None of the ewes had a severe reaction to the LPS challenge. The T10 and T11 ewes were calm after LPS infusion and did not present signs of pain or hypersensitivity, although 2 ewes of each treatment showed udders with moderate swelling and tissue hardness approximately $4 \mathrm{~h}$ after infusion. Clinical signs were similar to those observed in an acute IMI.

Body temperature, measured by vaginal temperature, of the T10 and T11 ewes increased after LPS infusion (Figure 3), peaking at 4 to $6 \mathrm{~h}$ after the challenge. In parallel, the vaginal temperature of $\mathrm{C} 00$ ewes slowly increased after milking as observed for ambient temperature and peaked $6 \mathrm{~h}$ after milking. Positive correlations of vaginal temperature $(y)$ with ambient temperature $(\mathrm{x})$ were detected for healthy ewes ( $\mathrm{y}=$ $0.072 \mathrm{x}+37.02 ; \mathrm{r}=0.55 ; P<0.001)$, indicating that the observed increased temperature was unlikely due to the IMI response and could be a consequence of the increase in ambient temperature, agreeing with data of experiment 1. Vickers et al. (2010) validated the use of vaginal loggers to measure body temperature; the technique has the advantage of not being affected by the presence of feces. Willard et al. (2007) also reported increased body temperatures after an endotoxin challenge in dairy cows, but the authors did not correlate this with the increased ambient temperature also recorded in their experiment.

The LPS dose used in our experiment was low compared with those used in dairy cows, which ranged between 0.02 and $2.60 \mu \mathrm{g} / \mathrm{kg}$ of BW of E. coli O55:B5 (Hovinen et al., 2008; Willard et al., 2007; respectively), but was sufficient to induce dramatic changes in milk appearance (milk flakes and yellow color) $6 \mathrm{~h}$ after the challenge; the 3 T11 ewes showed abundant flakes in their milk. A higher dose was used by Scott et al. (2000) in dairy cows but no information is available on the E. coli serotype used. Udder swelling disappeared gradually and was barely detectable $24 \mathrm{~h}$ after the challenge, as reported in dairy cows (Scott et al., 2000).

Milk Yield and Composition. Regarding milk production, all groups of ewes showed decreased milk yield on the day of treatment, which may have been a consequence of the experimental management and isolation of the ewes from the flock on the day before (Sufka and Hughes, 1991). Nevertheless, in agreement with the IMI signs of the T10 and T11 ewes, a greater milk yield decrease was observed in the LPS-treated udder halves after infusion (Figure 4). On average, the daily milk yield decreases in the treated (T10 and T11) 


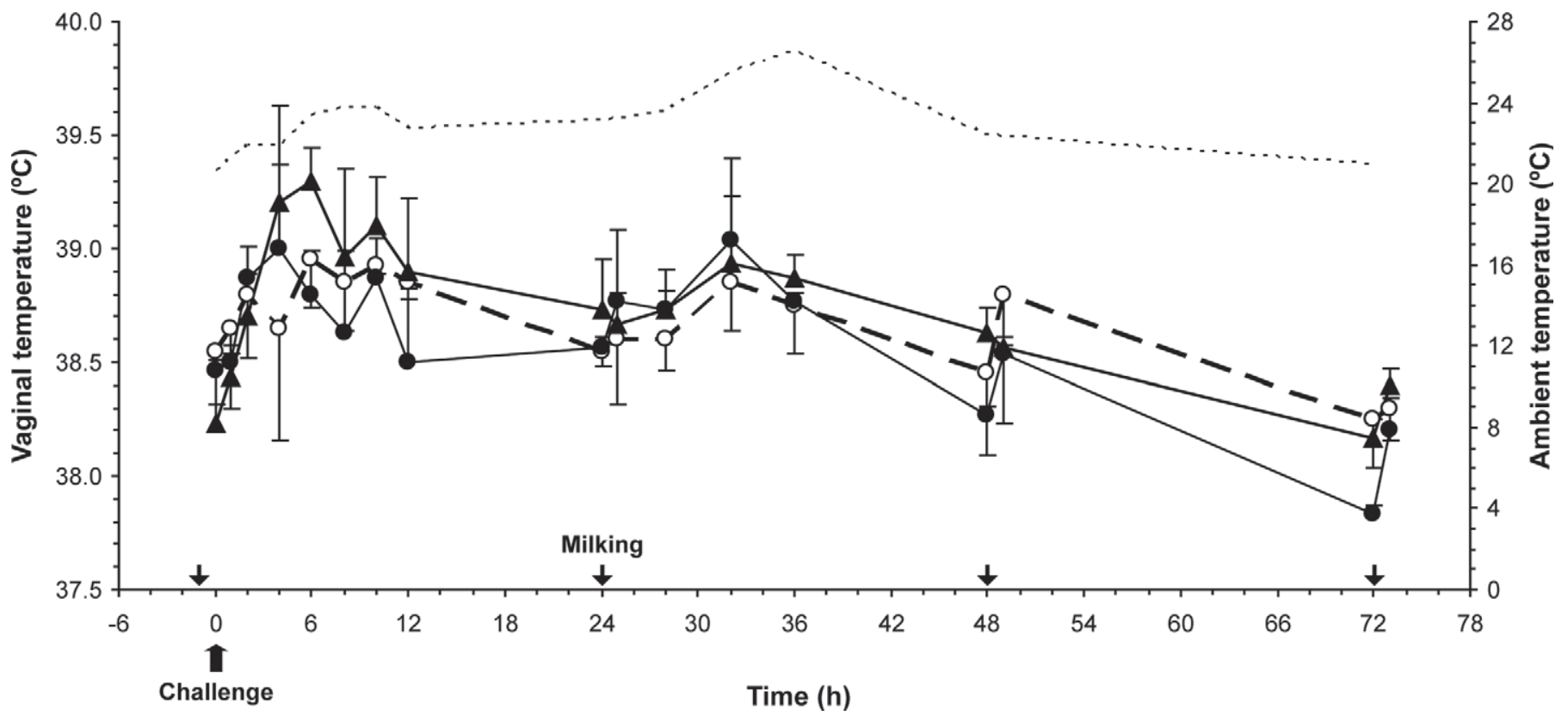

Figure 3. Changes in vaginal temperature of dairy ewes submitted to an Escherichia coli LPS challenge at late-lactation. Treatments by udder half were as follows: both udder halves untreated $\left(--\mathrm{O}_{-}, \mathrm{C} 00\right.$, control), half udder treated (- - , T10 and C01, one udder half was LPS infused and the other half was untreated, respectively), and both udder halves treated (- - , T11, both udder halves were LPS infused). Experimental details: E. coli challenge $(0 \mathrm{~h})$, once-daily milking $(\downarrow)$, and ambient temperature in the barn (---). Values are means with SEM indicated by error bars.

compared with the untreated (C00 and $\mathrm{C} 01)$ udder halves at 24,48 , and $72 \mathrm{~h}$ postchallenge were $-33.1(P$ $<0.05),-41.4(P<0.001)$, and $-36.6 \%(P<0.001)$, respectively, compared with that at $0 \mathrm{~h}$. All ewes showed increased milk yield at $48 \mathrm{~h}$ except the T10 ewes, in which milk yield plateaued but recovered at $72 \mathrm{~h}$. As a consequence, $\mathrm{C} 00$ and $\mathrm{C} 01$ ewes recovered their initial milk yield before the challenge, whereas the T10 and

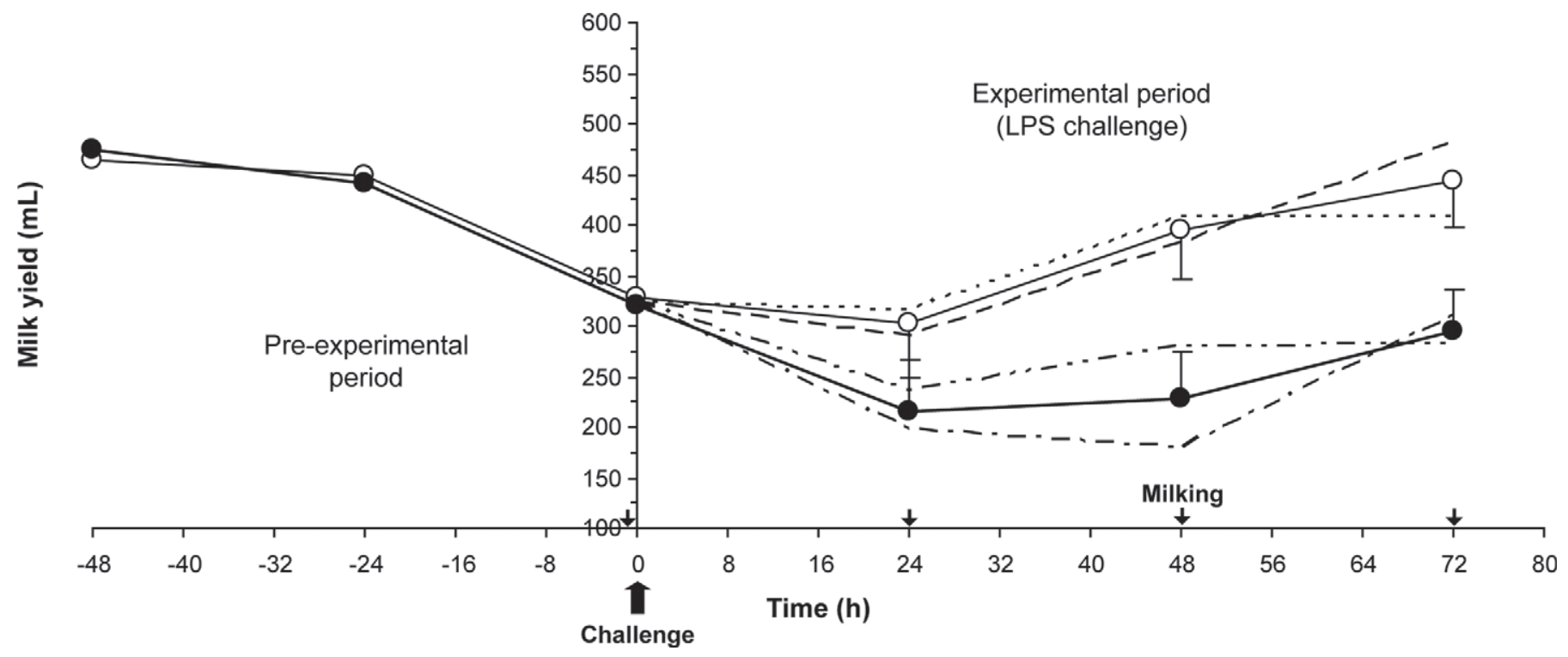

Figure 4. Effect of the infusion of Escherichia coli LPS on the milk yield of dairy ewes at late-lactation by half udder $(\bigcirc$, untreated; $\bullet$, LPS infused). Treatments were as follows: both udder halves untreated (---, C00, control), half udders treated (-- - -, C01, untreated udder half; -.---, T10, treated udder half) and both udder halves treated (-..-.--, T11, both udder halves infused). Experimental details: E. coli challenge $(0 \mathrm{~h})$ and once-daily milking $(\downarrow)$. Values are least squares means with SEM indicated by error bars. 
Table 2. Effect of Escherichia coli LPS infusion treatments on milk composition by udder half of dairy ewes at the end of lactation

\begin{tabular}{|c|c|c|c|c|c|c|}
\hline \multirow{3}{*}{$\begin{array}{l}\text { Item } \\
\text { and time }\end{array}$} & \multicolumn{4}{|c|}{ Treatment $^{2}$} & \multirow[b]{3}{*}{ SEM } & \multirow{3}{*}{$\begin{array}{c}\text { Treatment } \\
\text { effect }(P=)\end{array}$} \\
\hline & \multicolumn{2}{|c|}{ Control } & \multicolumn{2}{|c|}{ LPS infused } & & \\
\hline & $\mathrm{C} 00$ & $\mathrm{C} 01$ & $\mathrm{~T} 10$ & $\mathrm{~T} 11$ & & \\
\hline \multicolumn{7}{|l|}{ Fat, $\%$} \\
\hline $6 \mathrm{~h}$ & $9.82^{\mathrm{ab}}$ & $9.33^{\mathrm{b}}$ & $7.96^{\mathrm{a}}$ & $8.26^{\mathrm{ab}}$ & 0.34 & 0.08 \\
\hline $24 \mathrm{~h}$ & 7.22 & 7.42 & 8.19 & 8.23 & 0.48 & 0.76 \\
\hline $48 \mathrm{~h}$ & 6.46 & 5.40 & 9.54 & 7.56 & 0.57 & 0.17 \\
\hline $72 \mathrm{~h}$ & 6.38 & 5.99 & 7.05 & 6.91 & 0.47 & 0.80 \\
\hline \multicolumn{7}{|c|}{ Fat yield, $\mathrm{g} / \mathrm{d}$} \\
\hline $6 \mathrm{~h}$ & - & - & - & - & - & - \\
\hline $24 \mathrm{~h}$ & 22 & 21 & 17 & 18 & 2 & 0.62 \\
\hline $48 \mathrm{~h}$ & 25 & 22 & 16 & 21 & 3 & 0.65 \\
\hline $72 \mathrm{~h}$ & 24 & 29 & 23 & 20 & 2 & 0.12 \\
\hline \multicolumn{7}{|l|}{ Protein, \% } \\
\hline $6 \mathrm{~h}$ & $6.04^{\mathrm{b}}$ & $5.80^{\mathrm{ab}}$ & $5.60^{\mathrm{ab}}$ & $5.55^{\mathrm{a}}$ & 0.06 & 0.04 \\
\hline $24 \mathrm{~h}$ & 6.07 & 5.94 & 7.33 & 6.80 & 0.19 & 0.10 \\
\hline $48 \mathrm{~h}$ & 6.03 & 6.02 & 7.89 & 6.60 & 0.23 & 0.15 \\
\hline $72 \mathrm{~h}$ & 6.44 & 6.17 & 6.48 & 6.09 & 0.10 & 0.35 \\
\hline \multicolumn{7}{|c|}{ Protein yield, g/d } \\
\hline $6 \mathrm{~h}$ & - & - & - & - & - & - \\
\hline $24 \mathrm{~h}$ & 20 & 17 & 14 & 14 & 2 & 0.50 \\
\hline $48 \mathrm{~h}$ & 25 & 23 & 14 & 18 & 2 & 0.20 \\
\hline $72 \mathrm{~h}$ & 26 & 31 & 24 & 18 & 2 & 0.05 \\
\hline \multicolumn{7}{|l|}{ Lactose, \% } \\
\hline $6 \mathrm{~h}$ & $4.46^{\mathrm{c}}$ & $4.51^{\mathrm{c}}$ & $2.73^{\mathrm{a}}$ & $3.47^{\mathrm{b}}$ & 0.12 & 0.001 \\
\hline $24 \mathrm{~h}$ & $4.29^{\mathrm{c}}$ & $4.48^{c}$ & $2.02^{\mathrm{a}}$ & $2.92^{\mathrm{b}}$ & 0.10 & 0.003 \\
\hline $48 \mathrm{~h}$ & $4.13^{\mathrm{c}}$ & $4.42^{\mathrm{c}}$ & $2.90^{\mathrm{a}}$ & $3.11^{\mathrm{a}}$ & 0.13 & 0.003 \\
\hline $72 \mathrm{~h}$ & $4.12^{\mathrm{ab}}$ & $4.23^{\mathrm{bc}}$ & $3.59^{\mathrm{a}}$ & $3.73^{\mathrm{ac}}$ & 0.13 & 0.002 \\
\hline \multicolumn{7}{|c|}{ Lactose yield, g/d } \\
\hline $6 \mathrm{~h}$ & - & - & - & - & - & - \\
\hline $24 \mathrm{~h}$ & 14 & 13 & 5 & 7 & 1 & 0.02 \\
\hline $48 \mathrm{~h}$ & 17 & 17 & 6 & 8 & 1 & 0.04 \\
\hline $72 \mathrm{~h}$ & 18 & 21 & 12 & 10 & 1 & 0.003 \\
\hline \multicolumn{7}{|l|}{ TS, \% } \\
\hline $6 \mathrm{~h}$ & $21.5^{\mathrm{bc}}$ & $20.6^{\mathrm{c}}$ & $17.5^{\mathrm{ab}}$ & $18.1^{\mathrm{a}}$ & 0.4 & 0.006 \\
\hline $24 \mathrm{~h}$ & 18.6 & 19.0 & 19.1 & 19.1 & 0.6 & 0.99 \\
\hline $48 \mathrm{~h}$ & 17.4 & 17.1 & 23.5 & 18.6 & 0.8 & 0.19 \\
\hline $72 \mathrm{~h}$ & 18.3 & 17.2 & 16.7 & 17.1 & 0.4 & 0.67 \\
\hline \multicolumn{7}{|c|}{ TS yield, $\mathrm{g} / \mathrm{d}$} \\
\hline $6 \mathrm{~h}$ & - & - & - & - & - & - \\
\hline $24 \mathrm{~h}$ & 59 & 54 & 39 & 42 & 5 & 0.29 \\
\hline $48 \mathrm{~h}$ & 73 & 67 & 37 & 52 & 6 & 0.19 \\
\hline $72 \mathrm{~h}$ & $71^{\mathrm{bc}}$ & $84^{\mathrm{c}}$ & $62^{\mathrm{ab}}$ & $50^{\mathrm{a}}$ & 5 & 0.001 \\
\hline \multicolumn{7}{|l|}{$\log _{10} \mathrm{SCC}$} \\
\hline $6 \mathrm{~h}$ & $5.66^{\mathrm{a}}$ & $5.88^{\mathrm{a}}$ & $7.22^{\mathrm{b}}$ & $7.27^{\mathrm{b}}$ & 0.06 & 0.001 \\
\hline $24 \mathrm{~h}$ & $5.46^{\mathrm{a}}$ & $5.91^{\mathrm{a}}$ & $6.24^{\mathrm{a}}$ & $7.32^{\mathrm{b}}$ & 0.17 & 0.005 \\
\hline $48 \mathrm{~h}$ & $5.32^{\mathrm{a}}$ & $5.49^{\mathrm{a}}$ & $7.28^{\mathrm{b}}$ & $7.13^{\mathrm{b}}$ & 0.05 & 0.001 \\
\hline $72 \mathrm{~h}$ & $5.24^{\mathrm{a}}$ & $5.27^{\mathrm{a}}$ & $6.37^{\mathrm{b}}$ & $6.69^{\mathrm{b}}$ & 0.07 & 0.001 \\
\hline
\end{tabular}

${ }^{\mathrm{a}-\mathrm{c}}$ Means within a row with different superscripts differ $(P<0.05)$.

${ }^{1}$ Time after the LPS challenge.

${ }^{2}$ Treatments by udder half were as follows: both udder halves untreated (C00, control); half udder treated (T10 and C01, one udder half was LPS infused and the other half was untreated, respectively); and both udder halves treated (T11, both udder halves were LPS infused).

T11 ewes showed incomplete recuperation after $72 \mathrm{~h}$. Lehtolainen et al. (2003) reported complete recovery of the udder of dairy cows on d 2 after the challenge, which was not observed in our results and may be a consequence of the involution stage of the mammary gland induced by the once-a-day milking at the end of lactation (Boutinaud et al., 2003).
Changes in milk components as a result of the LPS challenge varied according to the milk component considered (Table 2), being moderate in fat, protein, and TS, and dramatic in lactose and SCC. The effects of LPS challenge on fat, protein, and TS contents were only significant $6 \mathrm{~h}$ after the challenge, and no effects were detected in corresponding daily milk yields, 


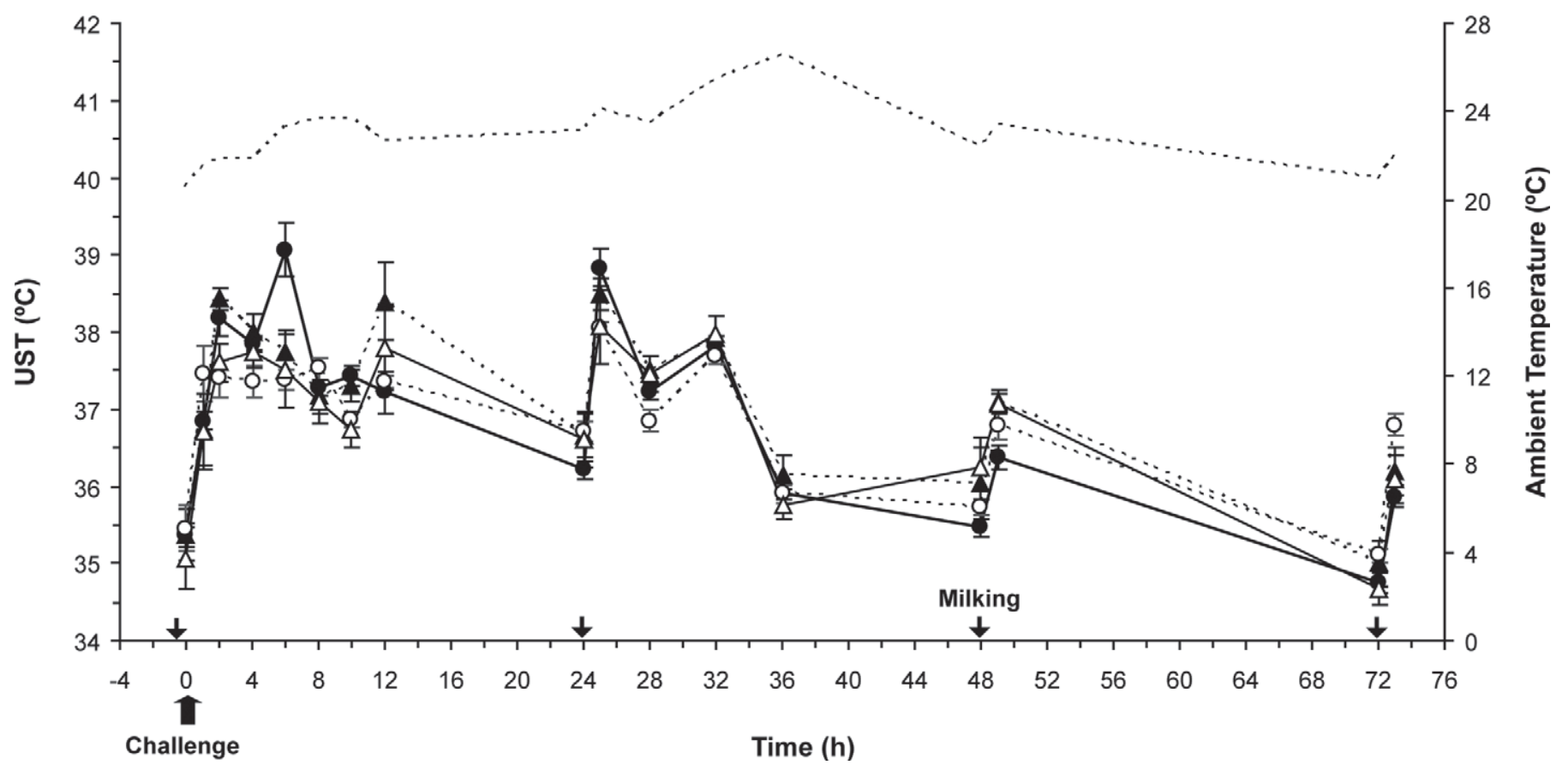

Figure 5. Changes in udder skin temperature (UST) of dairy ewes submitted to an Escherichia coli LPS challenge in late lactation. Treatments by udder half were as follows: both udder halves untreated $(\mathrm{O}, \mathrm{C} 00$, control), half udder treated $(\boldsymbol{\Delta}$, T10 and C01, one udder half was LPS infused and the other half was untreated, respectively), and both udder halves treated (๑, T11, both udder halves were endotoxin infused). Experimental details: E. coli challenge $(0 \mathrm{~h})$, once-daily milking $(\downarrow)$, and ambient temperature in the barn $(---)$. Values are means with SEM indicated by error bars.

except in TS yield at $72 \mathrm{~h}$, which was beginning to recover (Table 2; $P>0.05$ ). Lactose content decreased dramatically in the T01 and T11 groups $6 \mathrm{~h}$ after the challenge $(P<0.001)$, showing a nadir at $24 \mathrm{~h}$ and signs of recovery at $72 \mathrm{~h}$ compared with the control groups (Table 2); similar effects were detected in lactose daily yield $(P<0.05)$. A decrease in lactose output was also reported by Leitner et al. (2004) in subclinical mastitis milk of dairy ewes, which was attributed to the local role of casein hydrolyzed peptides on the activity of mammary epithelial cells (Silanikove et al., 2000). Martins et al. (2013) also reported lower lactose levels in the milk of ewes with clinical mastitis, supporting the theory that the damage to secretory tissue leads to a decrease in lactose biosynthesis. On the other hand, $\log _{10}$ SCC increased in the milk of the LPS-treated groups (13 to $26 \%, P<0.005$; Table 1 ) and remained high during the experiment (Lehtolainen et al., 2003), the effect being consistent $72 \mathrm{~h}$ after the LPS challenge and with the decrease in milk lactose contents. These results confirm the adequacy of the LPS dose used in our ewes and the persistency of the mastitis clinical signs discussed above, agreeing with those reported by Hovinen et al. (2008) in dairy cows treated with a low dose of endotoxin.
$\boldsymbol{U S T}$. Dramatic changes in UST values were shown throughout the experimental period; UST peaked 2 to $6 \mathrm{~h}$ after milking. Indoor ambient temperature, also shown in Figure 5, was $23.00 \pm 0.38^{\circ} \mathrm{C}$ on average, ranging between 20.6 and $26.6^{\circ} \mathrm{C}$ during the experiment, peaking at $36 \mathrm{~h}$, and slowly declining thereafter.

A circadian rhythm pattern was observed daily for UST, with minimum and maximum values before and after milking, respectively (Figure 5). This pattern indicated the influence of the variation in the daily temperature and management conditions. Nevertheless, no differences between treatments were observed for mean UST values during the experiment $(P=0.75)$, with the exception of T11, which showed a peak $6 \mathrm{~h}$ after the challenge $(P<0.001)$.

The lack of difference in mean UST values by effect of treatment agreed with the fact that UST values largely varied between udder halves of the same animal despite the treatment applied. The range of differences between udder halves of the same animal were high for $\mathrm{C} 00\left(0.05\right.$ to $\left.0.55^{\circ} \mathrm{C}\right)$ and $\mathrm{T} 10\left(0.05\right.$ to $\left.0.85^{\circ} \mathrm{C}\right)$ and increased in the case of $\mathrm{T} 11\left(0.10\right.$ to $\left.1.00^{\circ} \mathrm{C}\right)$, indicating large local variation in the UST values of healthy halves and in response to infection in the LPS-infused udder halves. These differences in response to an endotoxin 
challenge between udder halves have not been reported previously. Our results agreed with those of Scott et al. (2000), Hovinen et al. (2008), and Pezeshki et al. (2011), which showed similar increases of UST in experimental and control halves, reflecting the systemic effect of the infused endotoxin. Moreover, positive correlations between vaginal and ambient temperature (indicated above), between UST (y) and vaginal (x) temperatures $(\mathrm{y}=2.241 \mathrm{x}-49.51 ; \mathrm{r}=0.55 ; P<0.001)$, and between UST $(\mathrm{y})$ and ambient $(\mathrm{x})$ temperatures $(\mathrm{y}=0.504 \mathrm{x}+$ $25.72 ; \mathrm{r}=0.71 ; P<0.001)$ in the healthy ewes also supported the lack of effects of the experimental treatments.

Barth (2000) and Polat et al. (2010) reported significant UST differences $\left(+0.5\right.$ and $+2.35^{\circ} \mathrm{C}$, respectively) in dairy cows between udder quarters with SCC below and above 100 and $400 \times 10^{3}$ cells $/ \mathrm{mL}$, respectively. Polat et al. (2010) also found a moderate positive correlation between UST and SCC $(\mathrm{r}=0.73)$ that was higher than that in our ewe data $(\mathrm{r}=0.25 ; P=0.03)$. Additionally, Colak et al. (2008) and Polat et al. (2010) found positive correlations between UST and CMT values by udder in dairy cows $(\mathrm{r}=0.92$ and $\mathrm{r}=0.86$, respectively), but the correlation of UST with CMT was lower and not significant in our data $(\mathrm{r}=0.18 ; P$ $=0.50$ ). These results did not allow us to discriminate between the UST values of LPS-infused and healthy udder halves in our data, the variation observed being attributed to individual and environmental differences.

Our results disagree with those of Polat et al. (2010), who found $83.5 \%$ sensitivity and $100 \%$ specificity for a cutoff of $34.7^{\circ} \mathrm{C}$ when udder quarters where classified as healthy or infected with subclinical mastitis $(>200$ $\times 10^{3}$ cells $/ \mathrm{mL}$ ). Previous research showed that commercial thermal cameras are capable of detecting UST changes of 1.0 to $3.0^{\circ} \mathrm{C}$ in cows undergoing intramammary infusion with E. coli endotoxin (Hovinen et al., 2008; Pezeshki et al., 2011). In our experiment, the thermal camera was able to detect the changes in UST of 1 to $1.3^{\circ} \mathrm{C}$ associated with the E. coli LPS challenge in ewes.

\section{CONCLUSIONS}

Thermal imaging was a simple, fast and noninvasive technique to measure the skin temperature of the mammary gland in dairy ewes at milking. Nevertheless, despite the resolution of the camera used $\left( \pm 0.15^{\circ} \mathrm{C}\right)$ and the SEM obtained for UST measures $( \pm 0.05$ to $\pm 0.24^{\circ} \mathrm{C}$ ), we were unable to discriminate between healthy, infected (subclinical or clinical), or LPS-infused udder halves in dairy ewes. Other factors (breed, ambient temperature, milking) can induce changes in UST greater than those observed after clinical or subclinical IMI.

\section{ACKNOWLEDGMENTS}

The authors are grateful to Ramon Costa and the team of Servei de Granges i Camps Experimentals of the UAB (Bellaterra, Barcelona, Spain) for the care of the animals and to Nic Aldam (Barcelona, Spain) for the English revision of the manuscript.

\section{REFERENCES}

Adams, D., and M. McKinley. 2009. The sheep. ANZCCART Fact Sheet A9. Australian and New Zealand Council for the Care of Animals in Research and Teaching, The University of Adelaide, Adelaide, Australia.

Aljumaah, R. S., E. M. Samara, and M. Ayadi. 2012. Influence of introducing machine milking on biothermal parameters of lactating camels (Camelus dromedarius). Ital. J. Anim. Sci. 11:e73.

Barth, K. 2000. Basic investigations to evaluate a highly sensitive infrared-thermograph technique to detect udder inflammation in cows. Milk Sci. Int. 55:607-609.

Berger, Y., P. Billon, F. Bocquier, G. Caja, A. Cannas, B. McKusick, P.-G. Marnet, and D. Thomas. 2004. Fundamentals of Sheep Dairying in North America. Cooperative Extension Publishing, University of Wisconsin Extension, Madison.

Berry, R. J., A. D. Kennedy, S. L. Scott, B. L. Kyle, and A. L. Schaefer. 2003. Daily variation in the udder surface temperature of dairy cows measured by infrared thermography: Potential for mastitis detection. Can. J. Anim. Sci. 83:687-693.

Boutinaud, M., C. Rousseau, D. H. Keisler, and H. Jammes. 2003. Growth hormone and milking frequency act differently on goat mammary gland in late lactation. J. Dairy Sci. 86:509-520.

Bouwknecht, J. A., B. Olivier, and R. E. Paylor. 2007. The stressinduced hyperthermia paradigm as a physiological animal model for anxiety: A review of pharmacological and genetic studies in the mouse. Neurosci. Biobehav. Rev. 31:41-59.

Colak, A., B. Polat, Z. Okumus, M. Kaya, L. E. Yanmaz, and A. Hayirli. 2008. Short communication: Early detection of mastitis using infrared thermography in dairy cows. J. Dairy Sci. 91:4244-4248.

D'Alterio, G., S. Casella, M. Gatto, M. Gianesella, G. Piccione, and M. Morgante. 2011. Circadian rhythm of foot temperature assessed using infrared thermography in sheep. Czech J. Anim. Sci. $56: 293-300$.

Hovinen, M. 2009. Udder health of dairy cows in automatic milking. MS Thesis. University of Helsinki, Helsinki, Finland.

Hovinen, M., J. Siivonen, S. Taponen, L. Hanninen, M. Pastell, A. M. Aisla, and S. Pyörälä. 2008. Detection of clinical mastitis with the help of a thermal camera. J. Dairy Sci. 91:4592-4598.

Kunc, P., I. Knížková, M. Přikryl, and J. Maloun. 2007. Infrared thermography as a tool to study the milking process: A review. Agric. Trop. Subtrop. 40:29-32.

Lam, T. J. G. M., B. H. P. van den Borne, J. Jansen, K. Huijps, J. C. L. van Veersen, G. van Schaik, and H. Hogeveen. 2013. Improving bovine udder health: A national mastitis control program in the Netherlands. J. Dairy Sci. 96:1301-1311.

Lehtolainen, T., S. Suominen, T. Kutila, and S. Pyörälä. 2003. Effect of intramammary Escherichia coli endotoxin in early- vs. latelactating dairy cows. J. Dairy Sci. 86:2327-2333.

Leitner, G., M. Chaffer, A. Shamay, F. Shapiro, U. Merin, E. Ezra, A. Saran, and N. Silanikove. 2004. Changes in milk composition as affected by subclinical mastitis in sheep. J. Dairy Sci. 87:46-52.

Loughmiller, J. A., M. F. Spire, S. S. Dritz, B. W. Fenwick, M. H Hosni, and S. B. Hogge. 2001. Relationship between mean body surface temperature measured by use of infrared thermography and ambient temperature in clinically normal pigs and pigs inoculated with Actinobacillus pleuropneumoniae. Am. J. Vet. Res. 62:676-681.

Martins, R. F. S., T. P. Paim, C. A. Cardoso, B. S. L. Dallago, C. B. de Melo, H. Louvandini, and C. McManus. 2013. Mastitis detection in sheep by infrared thermography. Res. Vet. Sci. 94:722-724. 
McDougall, S., P. Murdough, W. Pankey, C. Delaney, J. Barlow, and D. Scruton. 2001. Relationships among somatic cell count, California mastitis test, impedance and bacteriological status of milk in goats and sheep in early lactation. Small Rumin. Res. 40:245-254.

McGavin, D., and J. F. Zachary. 2007. Pathologic Basis of Veterinary Disease. 4th ed. Mosby Elsevier, St. Louis, MO.

Mitchell, M. A. 2013. Thermal imaging in physiology: Theoretical and practical considerations. Pages 47-65 in Thermography: Current Status and Advances in Livestock Animals and in Veterinary Medicine. F. Luzi, M. A. Mitchell, L. Nanni Costa and V. Redaelli, ed. Fondazione Iniziative Zooprofilattiche e Zootecniche-Brescia, Brescia, Italy.

Murgia, L., C. Stelletta, M. Caria, M. Gianesella, M. Gatto, A. Pazzona, and M. Morgante. 2008. Using infrared thermography to monitor the effect of different milking vacuum levels on teat tissue in dairy ewes. Pages 131-140 in Proc. Int. Conf. Agric. Eng., Hersonissos, Greece. European Soc. Agric. Eng., Silsoe, UK.

NMC (National Mastitis Council). 1999. Laboratory and Field Handbook on Bovine Mastitis. National Mastitis Council Inc., Arlington, VA.

Olde Riekerink, R. G. M., H. W. Barkema, D. F. Kelton, and D. T. Scholl. 2008. Incidence rate of clinical mastitis on Canadian dairy farms. J. Dairy Sci. 91:1366-1377.

Pezeshki, A., P. Stordeur, H. Wallemacq, F. Schynts, M. Stevens, P. Boutet, L. J. Peelman, B. De Spiegeleer, L. Duchateau, F. Bureau, and C. Burvenich. 2011. Variation of inflammatory dynamics and mediators in primiparous cows after intramammary challenge with Escherichia coli. Vet. Res. 42:15.

Piccione, G., and G. Caola. 2003. Influence of shearing on the circadian rhythm of body temperature in the sheep. J. Vet. Med. A Physiol. Pathol. Clin. Med. 50:235-240.
Polat, B., A. Colak, M. Cengiz, L. E. Yanmaz, H. Oral, A. Bastan, S. Kaya, and A. Hayirli. 2010. Sensitivity and specificity of infrared thermography in detection of subclinical mastitis in dairy cows. J. Dairy Sci. 93:3525-3532.

Rebhun, W. C. 1995. Diseases of Dairy Cattle. Lea and Febiger/Williams \& Wilkins, Philadelphia, PA.

Scott, S. L., A. L. Schaefer, A. K. W. Tong, and P. Lacasse. 2000. Use of infrared thermography for early detection of mastitis in dairy cows. Can. J. Anim. Sci. 80:764. (Abstr.)

Silanikove, N., A. Shamay, D. Sinder, and A. Moran. 2000. Stress down regulates milk yield in cows by plasmin induced $\beta$-casein product that blocks $\mathrm{K}^{+}$channels on the apical membranes. Life Sci. 67:2201-2212.

Sufka, K. J., and R. A. Hughes. 1991. Differential effects of handling on isolation-induced vocalizations, hypoalgesia, and hyperthermia in domestic fowl. Physiol. Behav. 50:129-133.

Vegricht, J., A. Machálek, P. Ambrož, U. Brehme, and S. Rose. 2007. Milking-related changes of teat temperature caused by various milking machines. Res. Agric. Eng. 53:121-125.

Vickers, L. A., O. Burfeind, M. A. G. von Keyserlingk, D. M. Vieira, D. M. Weary, and W. Heuwieser. 2010. Comparison of rectal and vaginal temperatures in lactating dairy cows. J. Dairy Sci. 93:5246-5251.

Viguier, C., S. Arora, N. Gilmartin, K. Welbeck, and R. O'Kennedy. 2009. Mastitis detection: Current trends and future perspectives. Trends Biotechnol. 27:486-493.

Willard, S., S. Dray, R. Farrar, M. McGee, S. Bowers, A. Chromiak, and M. Jones. 2007. Use of infrared thermal imaging to quantify dynamic changes in body temperature following lipopolysaccharide (LPS) administration in dairy cattle. J. Anim. Sci. 85(Suppl. 2):26. (Abstr.) 